\title{
Editorial
}

\section{Psychology's Recovery of its Proper Projects and Methods}

\author{
Rom Harré ${ }^{a}$ \\ [a] Psychology Department of Georgetown University, Washington, DC, USA.
}

Europe's Journal of Psychology, 2012, Vol. 8(3), 315-320, doi:10.5964/ejop.v8i3.493

Received: 2012-07-09. Accepted: 2012-07-11. Published: 2012-08-29.

${ }^{*}$ Corresponding author at: Psychology Department, Georgetown University, Washington, DC 20057, email: harre@georgetown.edu.

(c) This is an open access article distributed under the terms of the Creative Commons Attribution License

(http://creativecommons.org/licenses/by/3.0), which permits unrestricted use, distribution, and reproduction in any medium, provided the original work is properly cited.

The contrast between a psychological and a biological study of a superficially similar phenomenon can be illustrated with the 'cough'. The word is used generically for an explosive expulsion of air that clears the pulmonary passages. But this common meaning is set into two radically different conceptual and empirical frameworks. Imagine you are at a concert - Yo Yo Ma is approaching one the most delicate passages in the Elgar Cello concerto and you become aware of a mounting discomfort in the chest and a well nigh irresistible pressure to cough - eventually you cannot control it any more. This is the 'cough' in a biological framework of mechanisms and concepts. Consider this case - you are at the open door of colleague's study and you see that she is earnestly advising an undergraduate. Rather than barge in you cough discretely to attract her attention. In the first case you, the person, have lost control of a biological mechanism, while in the second case you, the person, used a biological mechanism for a psychologically intelligible purpose. In the first case the cough has no meaning. In the second case its meaning is or ought to be clear. Note too, that different cultures may have different uses for the cough, just as different cultures have different uses for the smile.

This parable has a larger import. Human life consists of two radically different unfolding patterns. There are practices, procedures which people adopt to accomplish the tasks that confront them as they strive to manage their everyday lives. Then there are biological processes of which people are only occasionally aware but which are necessary for the maintenance of life. Digging the garden in the spring is a practice - a pattern of deliberate acts in conformity with a cluster of standards that may have become 'second nature' - the sod should be so many centimetres deep and the furrow should be straight and so on. So too displaying one's displeasure at being 'dissed' by an angry response is a practice - in certain circumstances it would be appropriate and in others disastrous. Like the cough an angry display has a meaning related to the meanings of what has gone on around the stroppy person. If I don't realise that I have been treated unfairly nothing that I subsequently do could be an angry gesture. Even digging has to be considered for its meaning - is it done to display my green credentials to a fossil fuel squandering neighbour?

This example has extraordinary consequences for the development of a 'psychology of the emotions'. There is surely a corporeal response to a situation depending on how the target reads it, that is what meaning is assigned 
to it. What the person then does is also relevant by reason of the meaning that that display has in the context and in that culture. A display of jealousy is a complex semantic phenomenon, registering a certain interpretation of the fortunes of another person, a judgment as to whether this person's good fortune is deserved relative to one's own and so on. This introduces considerations of rights and duties, opening up the question of the nature of the local moral order. The tip of the 'jealousy' iceberg may be a forced smile, but the bulk of the phenomenon is semantic and embedded in cultural niceties. As a person becomes skilled in social life the display of jealousy may be entirely private.

But why is there any need to emphasise the discursive character of psychological phenomena and psychological activities as meaning management?

\section{The Puzzle of Paradigm Paralysis in Psychology Compared With Physics}

Jan Valsiner's admirable presentation of methodology for cultural psychology (Valsiner, 2007). produces a strong feeling of deja vu for those of us who were actively trying to bring psychology forwards in the 1960s and 70s. For example the use of disruption of routines to bring to light the implicit rule systems that were implemented by social actors is very similar to ethnomethodology (Garfinkel, 1967) and its use of account analysis.

At that time there was a vigorous movement all over Western Europe to abandon the simple 'experimental' psychology of the American mainstream in favor of what we would now call qualitative/cultural studies. For example, at Oxford there was Michael Argyle's social psychology group producing studies such as Marsh's investigation of the social psychology of football 'hooliganism' (Marsh, Rosser, \& Harré, 1978) and Jerome Bruner's (1986) work on the developmental dimension of intentionality; there was Moscovici (1993) and Jodelet (1991) in Paris and their colony at the LSE who were all involved in the extraction of social representations from the flux of everyday life; there was Jan Smedslund's (1988) development of psychologic, the identification of semantic tautologies in the everyday language of psychology in Oslo; there was Nardone and Salvini's (2007) studies of the life of the street in Rome; Jose Luis Rodriguez-Lopez' (1988) historical analysis of the changing personal beliefs about 'loyalty to the telephone company' in Madrid; Mario von Cranach' studies of the planning and execution of complex goal directed activities in Berne (von Cranach \& Harré, 1982); Tom Luckmann's (1983) work on the social distribution of bodies of knowledge in Vienna; and so on. Despite founding of journals and the success of Harré and Secord's (1972) book, 'The Explanation of Social Behaviour' when we now reflect on the state of psychology as exemplified in such conservative journals as the European Journal of Social Psychology, the old paradigm still reigns, and tragically, young psychologists in many places now do second/third rate studies in that mode. During the crucial period the US was Top Nation. Now the US is declining as Top Nation, yet the old paradigm that emerged from a marriage of the ghost of behaviorism with the imported Viennese philosophy of logical positivism, continues on.

Here is the puzzle. The same thing did not happen in physics. Throughout the $19^{\text {th }}$ century Britain was Top Nation and physics was dominated by Newtonian mechanics, refined and extended to just about everything. But in 1905 a new physics developed in the German speaking world, by Einstein, Schrodinger, Heisenberg and many others with a very different conceptual framework. Very soon it displaced the old paradigm so much so that some of leading members of the new wave such as Paul Dirac were British. And this came about despite the catastrophe that overtook Germany in the First World War. Of course after that war despite coming out victorious Britain gradually ceased to be Top Nation. 
What was the difference? All along, the new paradigm (NP) crowd in psychology have accused the old paradigm adherents (OP) of violating the major tenets of scientific research and theorizing. But the OP did not take any notice. In the period 1905 - 1935 while physics was changing, everyone agreed on what scientific research and the theorizing involved. In the period 1965 - 1975 in psychology there was no such agreement. Why? The NP psychologists were inspired by the actual methods of the physical sciences, such as iconic model building, the development of topic relevant taxonomies of phenomena and so on, but the OP people were inspired by a bit of philosophy that was soon discarded by philosophers of science, namely logical positivism, especially that of Ernst Mach and the Vienna Circle. Almost all the self-destructive features of the OP can be traced to its influence, though by the time it had become the dominant research paradigm in the 1960s and 70s its protagonists had lost touch with its origins.

Here are a few examples - in physics/chemistry 'model' means analogue, and it is usually models that one studies, rarely the real thing. In psychology 'model' seems to mean 'idea', 'concept', 'interpretation' even 'theory', but almost never 'analogue'. From a clear methodological concept and procedure in physics and chemistry we enter a murky world of ambiguity in psychology. Generalizing: in physics and chemistry does not mean making a statistical analysis and deleting the instances that do not fit, but rather by proposing a possible pattern and by using the intensive design construct or identify a range of similar cases, large or small! This chlorine sample produced in my lab is typical [but of course there are isotopes!]. This sample of conformity to the majority in my lab is only relevant if conjoined with a number of other instances and processed to reveal the typical case, which might be found nowhere (Lamiell, 2003). In psychology there is generalizing by statistical analysis of the distribution of responses in a small sample - 30 Ann Abor undergraduates stand in for the whole of humanity! This presumes a commonality of psychological practices that ought to be the end product of centuries of research rather a presumption of the beginning.

We want to shift the focus of psychology from simplistic experiments, in which the meanings of the phenomena for participants (please - not subjects!) and experimenters are unknown, to a proper mix of psychoneurology and qualitative, that is cultural/discursive psychology. We are aiming at creating a human science that is in accordance with what physicists and chemists really do, not what a bunch of antiquated and flawed philosophers tell them they should be doing!

\section{Can Wittgenstein Save Cognitive Neuroscience?}

At this moment neuropsychology is dominating the generosity of the grant giving agency despite the striking criticisms of the very idea of such a project. Still much in the same position as the tiny mammals scuttling among the giant limbs of the dinosaurs a flourishing a program of cultural/discursive psychology already exists and is becoming more popular. Must these programs stand in hostile opposition to one another? I believe that they can actually be shown to depend upon one another. The marriage of neuroscience and cultural/discursive psychology is based on the insights of many critics of the causal framework for psychology, but one philosopher in particular, was Ludwig Wittgenstein who came to it from disenchantment with simplistic ideas about meaning. His insights can be deployed as a basis for a working hybrid science, though this was not his intention.

The fundamental principle of the many facets of the cultural/discursive approach that underlies qualitative and cultural psychologies of the present time is that the instruments of cognition are symbols. The meanings of these diverse entities are the uses to which people have, do and maybe will put them. Hybrid psychology depends on 
the intuition that while brains can be assimilated into the world of persons, as among the instruments people use for carrying out many of their projects, people cannot be assimilated into the world of cell structures and molecular processes. To suppose that they can be has been called the 'mereological fallacy' - ascribing attributes of wholes to some of their parts (Bennett \& Hacker, 2003). People think. Brains, parts of people, do not. However, unlike our biological ancestors, our instrumentarium is rich in symbolic tools, managed by the skillful use of bodily organs, the first order tools that training and practice have shaped into fitting instruments for the use of symbolic systems, such as words, hammers, tennis racquets, flags and so on (Harré \& Moghaddam, 2012).

The idea that we should extend this insight to think of our bodies as tools needs to be expressed with care. Hands are tools for all sorts of tasks. Should we say that brains and their components are also tools? We need to make clear the subtleties that have to be taken into account in proposing that we should think of our brains and their constituent organs instrumentally as tools, in the context of psychology as a science. Whatever medium is being used at any moment and for any task the social origins of human cognitive practices, as Vygotsky (1986) demonstrated, must not be forgotten.

Three Wittgenstein insights are most important: (1) the private language argument - symbols are essentially social; (2) the rejection of age old but vicious dichotomies such 'mind and body' and developing alternatives, such as 'private/public', 'individual/social' to frame psychological investigations; (3) the idea of fields of family resemblance, in which we take account of the context dependence of the meanings of key terms such 'intention', 'remembering, 'grief' and so on, rather than artificially inventing a common meaning and seeking in vain for a suitable referent. These are displayed by Wittgenstein (1953/2001) in his great work, the Philosophical Investigations. Detailed accounts of how these insights can be put to work in cultural/discursive psychology can be found in Harré and Tissaw (2005).

\section{What Should Empirical Research Look Like?}

What are the phenomena? According to the cultural/discursive paradigm they are patterns of meanings, a flux every moment of which is modulating and transforming as meanings shift and change.

What are the analytical and explanatory models? They are discourses, treated dialogically, and systems of implicit and explicit rules, cultural conventions and normatively disciplined practices. These are essential features of the formation and maintenance of persons as selves (Hermans \& Hermans-Konopka, 2010).

What are the universals? We do not know, but we take care to add history and anthropology to our range of resources.

What drives the processes thought, action, feeling and perception on? People are to be presumed to be active agents - the unitas multiplex, of William Stern (Lamiell, 2010).

Research methods should be aimed at discovering the working lexicon of meanings in use among the people of a certain cultural group as they think, act, feel and perceive, primarily in social-public interactions and secondarily in private-individual activities that must bear the stamp of their dialogical Vygotskean origins. The next step would be to identify the projects that people are likely to be undertaking and the goals intermediate and final that mark their progress. All of this is set in a matrix of rules, conventions, habits and other learned patternings of meaningful phenomena. Only from a data base assembled from very many local research undertakings would it be legitimate 
to try to extract some discursive means that might be found among every human tribe. This raises a deep question - how it is possible for an outsider to understand the psychology of a remote culture - the paradox of translation.

Looked at from a wider perspective adopting the cultural/discursive paradigm involves abandoning the use of causal concepts in psychology in favour of concepts drawn from linguistic interactions as models for psychology generally. Instead of trying to show that a sequence of events are linked causally, that is a prior event or state as the necessary and sufficient condition to the coming to be of the subsequent event or state, we should see patterns of thought, feeling, acting and perceiving as linked semantically. It is the meaning of a prior act or experience that leads on the subsequent act, thought or feeling as a contribution to a meaningful sequence. The meaning patterns of conversations, the dialogical shaping of human behaviour (Hermans \& Hermans-Konopka, 2010) provide the best models for a scientific psychology.

\section{References}

Bennett, M. R., \& Hacker, P. M. S. (2003). Philosophical foundations of neuroscience. Malden, MA: Blackwell.

Bruner, J. S. (1986). Actual minds: Possible worlds. Cambridge, MA: Harvard University Press.

Garfinkel, H. (1967). Studies in ethnomethodology. Englewood Cliffs, NJ: Prentice Hall.

Harré, R., \& Moghaddam, F. M. (2012). Psychology for the third millennium: Integrating cultural and neuroscience perspectives. London: Sage.

Harré, R., \& Secord, P. F. (1972). The explanation of social behaviour. Oxford: Blackwell.

Harré, R., \& Tissaw, M. A. (2005). Wittgenstein And Psychology: A Practical Guide. Aldershot: Ashgate.

Hermans, H. J. M., \& Hermans-Konopka, A. (2010). Dialogical self theory: Positioning and counter-positioning in a globalizing society. Cambridge: Cambridge University Press.

Jodelet, D. (1991). Madness and social representations: Living with the mad in one French community. New York: Harvester.

Lamiell, J. T. (2003). Beyond individual and group differences: Human individuality, scientific psychology, and William Stern's critical personalism. Thousand Oaks: Sage.

Lamiell, J. T. (2010). William Stern. Lengerech: Pabst.

Luckmann, T. (1983). Life-world and social realities. London: Heinemann.

Marsh, P., Rosser, E., \& Harré, R. (1978). The rules of disorder. London: Routledge.

Moscovici, S. (1993). The invention of society: Psychological explanations for social phenomena. Cambridge: Polity.

Rodriguez Lopez, J. L. (1988). Viejos Valores y Nuevas Burocracias. Madrid: Ministerio de Trabao Publicaiones.

Nardone, G., \& Salvini, A. (2007). The strategic dialogue. London: Karnac.

Smedslund, J. (1988). Psycho-logic. Berlin: Springer Verlag.

Valsiner, J. (2007). Culture in minds and societies: Foundations of cultural psychology. New Delhi: Sage. 
von Cranach, M., \& Harré, R. (1982) The analysis of action: Recent theoretical and empirical advances. Cambridge, MA:

Cambridge University Press.

Vygotsky, L. S. (1986). Thought and Language. Cambridge, MA: MIT Press.

Wittgenstein, L. (2001). Philosophical Investigations. Oxford: Blackwell. (Original work published 1953)

\section{About the Author}

Rom Harré is an illustrious philosopher and psychologist, currently Distinguished Professor in the Psychology Department of Georgetown University and Director of the Centre for Philosophy of Natural and Social Science, LSE. He began his career in mathematics and physics and later focused on the philosophy of science, completing a B.Phil at the University of Oxford (Linacre College) under the supervision of J. L. Austin. Professor Harré has published widely in a variety of psychological and philosophical fields including causality, realism, language and cognitive science. Notable titles: 'Causal Powers' (with E. H. Madden), 'Varieties of Realism', 'Modelling: Gateway to Nature', 'The Explanation of Social Behaviour' (with P. F. Secord), 'Cognitive Science: A Philosophical Introduction'. Among his most recent books is 'Pavlov's and Schrodinger's cat', a study of the uses of animals and plants as scientific apparatus, as well as an edited volume (with Fathali Moghaddam) entitled 'Psychology for the Third Millennium'. Professor Harré held Visiting Professorships in many places, including Australia, Spain, and Japan. 